\title{
Selection of Appropriate Coastal Protection Structure Using AHP Method ${ }^{+}$
}

\author{
Barbara Karleuša *, Nino Krvavica and Igor Ružić \\ Faculty of Civil Engineering, University of Rijeka, 51000 Rijeka, Croatia; nino.krvavica@uniri.hr (N.K.); \\ iruzic@uniri.hr (I.R.) \\ * Correspondence: barbara.karleusa@uniri.hr; Tel.: +385-51-265-935 \\ + Presented at the 4th EWaS International Conference: Valuing the Water, Carbon, Ecological Footprints of \\ Human Activities, Online, 24-27 June 2020.
}

Published: 8 August 2020

\begin{abstract}
The selection of an appropriate coastal protection structure using multi-criteria analysis method AHP (analytic hierarchy process) was presented by a case study of a beach reconstruction in the Kostanj Bay (north-western part of Croatia). The newly designed beach (about $300 \mathrm{~m}$ long) will be formed on the western part of the bay by the additional filling of the natural rocky coastline with gravel and building reinforced concrete seawalls towards the sea. The beach will be protected by a submerged breakwater. Five different alternatives were analysed and defined by a different design of the protective breakwater. The first alternative, without the submerged breakwater, was considered as the baseline alternative. An additional four alternatives were examined based on four criteria and five sub-criteria, which considered the technical, economic, social and environmental impacts. The sensitivity of the ranking for the considered alternatives was analysed using five criteria importance scenarios.
\end{abstract}

Keywords: analytic hierarchy process; AHP; coastal protection; multi-criteria analysis; structures; submerged breakwater

\section{Introduction}

The complexity of decision making in coastal management is a result of multiple objectives that must be satisfied, different criteria and measures that are used to valorise the achievement of these objectives, and the multiple stakeholders that are usually involved in the process. To support this kind of decision-making processes, different methods can be applied, such as multi-criteria analyses (MCA) methods [1-4]. MCA methods have been regularly applied in coastal management: for determining coastal vulnerability to wave impacts using the AHP (analytic hierarchy process) method and GIS in Santa Catarina Spain [5]; defining priority actions for waterfront development incorporating local stakeholder preferences using developed MCA method ENCoRe in Greece [6]; selecting deep-water sea port's construction site using AHP and fuzzy ratio assessment (ARAS-F) methods in the Baltic Sea [7]; and identifying and prioritizing critical infrastructure vulnerabilities in the coastal community of Scarborough, Maine, USA, using AHP [8].

This paper presents the methodology for selecting an appropriate coastal protection structure (construction of protective submerged breakwater) using multi-criteria analysis method AHP, which was demonstrated by a case study for the beach reconstruction in the Kostanj Bay (located in the north-western part of Croatia, near the city of Rijeka). Five alternatives were analysed according to four criteria and five sub-criteria. The importance of each criterion and sub-criterion are defined by a different weight factor.

The aims of this paper were threefold: first, verify whether the AHP method is suitable for decision making in coastal management when selecting an optimal breakwater design; second, 
present a methodology for preparing the input data for the AHP analysis of a specific case study; third, give some suggestion for the AHP application on similar problems in coastal management and for further research.

\section{Materials and Methods}

\subsection{AHP Method}

AHP is a priority method applicable to problems that can be represented by a hierarchical structure [9]. The top of the hierarchy is the goal, one level lower are the criteria, and there is the possibility of adding more levels for sub-criteria. The lowest level is represented by alternatives. The AHP method is based on estimating the pair-wise relative priorities (weight, importance, preference) of criteria to the goal and alternatives to each (sub)criterion. Pair-wise comparison matrix for criteria with respect to the goal, and pair-wise comparison matrices for alternatives (one matrix for each criterion) were generated using a pair-wise comparison scale shown in Table 1 . This method also allows a direct assessment of the criteria regarding the goal and of the alternatives regarding each criterion, which was applied only to criteria importance in this research.

Table 1. The AHP (analytic hierarchy process) method pair-wise comparison scale [9].

\begin{tabular}{cc}
\hline Intensity of Weight, Importance, Preference & Definition \\
\hline 1 & Equal importance (no preference) \\
3 & Moderate importance (moderate preference) \\
5 & Strong importance (strong preference) \\
7 & Very strong importance (very strong preference) \\
9 & Extreme importance (extreme preference) \\
$2,4,6,8$ & Intermediate values \\
\hline
\end{tabular}

The columns in matrices are normalized in order to calculate the priority vector for criteria and the priority vectors for alternatives regarding each criterion. As a result, the overall priority matrix of alternatives is formed in which the columns are priority vectors of alternatives for each criterion. The overall priority vector of alternatives is calculated by multiplying this matrix with the priority vector of criteria. The overall priority vector defines the priority (weight) of each alternative with respect to the goal so that the ranking of alternatives can be defined. In the case of the pair-wise comparison of alternatives or criteria, the consistency of pair-wise comparison matrices of alternatives and criteria, as well as the overall priority matrix are evaluated by computing the inconsistency index (which should be lower than 0.1) to assure that the judgments are consistent. For ranking alternatives using the multi-criteria method AHP, the following steps should be performed:

- Defining the problem (the goal, the criteria, the alternatives) and defining the hierarchy;

- Performing a pair-wise comparison of criteria in respect to the goal or defining the weight/importance of each criterion (this must be done also for sub-criteria with respect to criteria);

- Performing a pair-wise comparison of the alternatives with respect to each criterion or evaluating the alternatives against each criterion;

- Applying the AHP method to estimate the overall priority vector of the alternatives with respect to the goal;

- Forming the rank-list of alternatives;

- Performing the sensitivity analysis;

- Making the final decision. 


\subsection{Case Study}

The case study analysed in this paper was the reconstruction of a beach in Kostanj Bay located in the north-western part of Croatia, in the city of Rijeka (Figure 1).

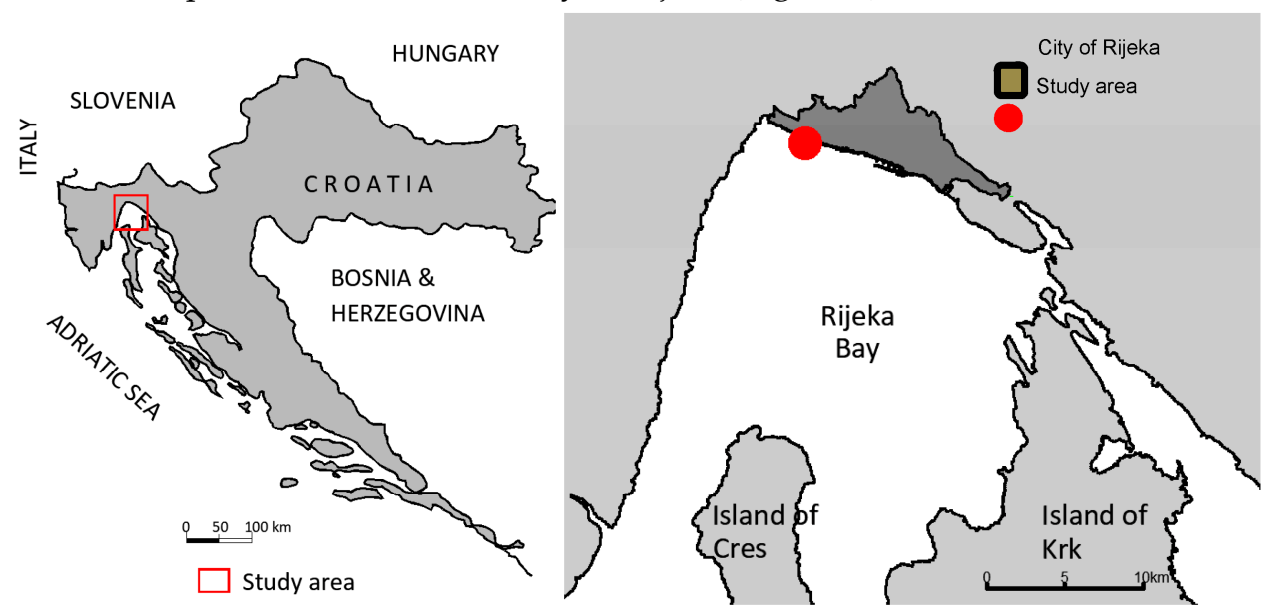

Figure 1. Location of the case study area.

The City of Rijeka is the third largest city in Croatia and the second largest coastal city. According to the 2011 Census, the city had a population of 128,624 inhabitants, with a metropolitan area of 245,054 inhabitants. Rijeka has a humid subtropical climate (Cfa) with warm summers and relatively mild winters. Although Rijeka has never been among the most popular tourist destinations in Croatia, it has gained noticeable interest as a cultural and tourist destination in recent years. The bathing season in Rijeka starts in spring and lasts until late autumn. A series of smaller and larger beaches are located on the eastern and western border of Rijeka. As a result of steep coastline, natural rocky beaches prevail, with several natural and artificial gravel beaches.

The Kostanj was the first public beach in Croatia adapted for people with disabilities. Since the current interests and needs surpass the capacity of 300 visitors, the City of Rijeka has decided to extend and reconstruct this beach. The newly designed beach will be formed upon the existing beach and will extend over a coastline length of approximately $300 \mathrm{~m}$, from the northeast to northwest. The beach will be extended by building reinforced concrete seawalls, with similar elevations to the existing beach. Experiences with the long-term maintenance of the Kostanj beach show increased nourishment activities every year before the start of the tourist season, as well as repeated repairs of concrete coastal elements damaged by increased erosion from waves. Therefore, as an additional element, a protective submerged breakwater is planned. This structure should contribute to the protection of other coastal structures from the destructive action of the sea waves, but also the reduction of the gravel beach erosion. The protective submerged breakwater was selected because it has good performance in dissipating wave energy and reducing wave heights in front of the beach structure, and it is well suited for the local site conditions characterised by a steep rocky shoreline. Alternative protective structures, including both soft and hard measures, were dismissed at the preliminary stage of the decision-making process because of their high costs or because they are less suited for local conditions (steep rocky shoreline, wave climate, etc.).

For this purpose, five alternatives, defined by a different design and position of the submerged breakwater, were considered. In alternative A1, the beach will be extended to the western part of the bay by filling the natural rocky coastline and constructing reinforced concrete seawalls, without any protective structure (a baseline alternative). The condition given by the investor was that a submerged breakwater should be placed for the beach protection, thus the alternatives from A2 to A5 have the same beach structure as A1, but they differ in the design, dimensions, and location of the protective submerged breakwater. Detailed information on each alternative is given in Figure 2 and Table 2.

Once the location, design, and dimensions of the submerged breakwater were defined, the performance of each alternative was tested by a numerical wave model [10]. Namely, to assess the 
performance of a breakwater in reducing wave heights and energy, a third-generation wave model SWAN was applied [11]. Although a submerged breakwater also affects the circulation and sediment transport, these processes are negligible in comparison to wave forces in these conditions. The model was forced by a 50 year return period wave spectrum defined by a significant wave height, $3.5 \mathrm{~m}$ from the south-southwest (SSE) direction. The spatial domain was defined by the bathymetry with superimposed breakwater geometry. The results from the SWAN model show a reduction in the significant wave heights in front of the new beach, as well as the wave energy dissipation at the breakwater [10]. These results were considered when comparing and evaluating the alternatives from the technical, economic, environmental, and social point of view (Table 2).
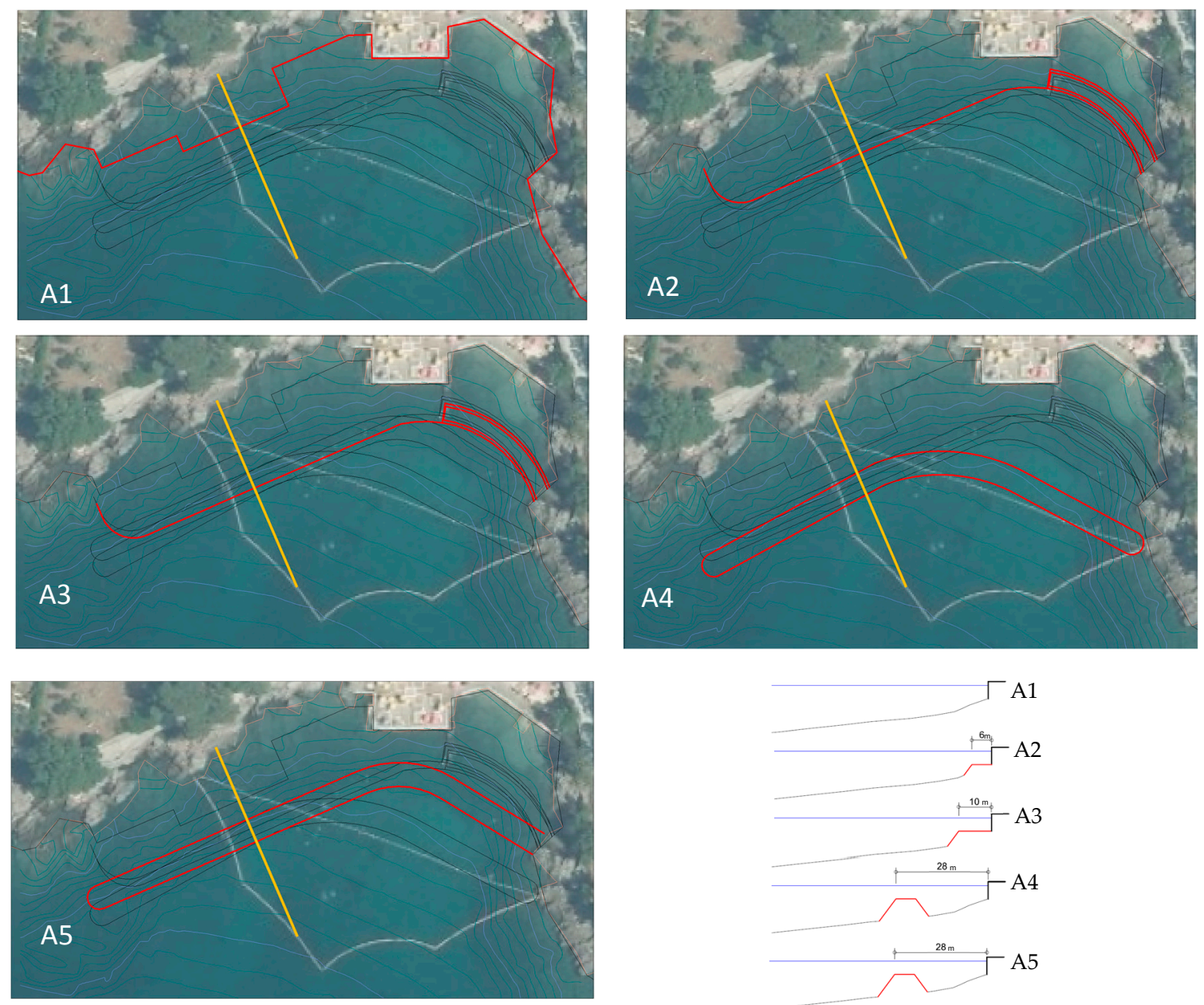

Figure 2. Alternatives A1-A5 of the coastal protection structures implementation and their crosssections (from [10]).

\section{Results}

\subsection{Definition of Criteria}

The goal of the MCA in this paper was to select the best breakwater design according to defined criteria and their importance. Four categories of criteria were defined considering the problem and its solutions (alternatives): the technical, economic, environmental, and social criteria. 
Table 2. Pairwise comparison of the alternatives.

\begin{tabular}{|c|c|c|c|c|c|c|c|}
\hline Alternatives & $\begin{array}{c}\text { Characteristics of the } \\
\text { Breakwater }\end{array}$ & $\begin{array}{l}\text { Complexity of the } \\
\text { Construction }\end{array}$ & $\begin{array}{c}\text { Decrease } \\
\text { in Wave } \\
\text { Height }\end{array}$ & $\begin{array}{l}\text { Wave Energy } \\
\text { Dissipation }\end{array}$ & $\begin{array}{c}\text { Protection of } \\
\text { Coastal } \\
\text { Structure }\end{array}$ & $\begin{array}{l}\text { Environmental } \\
\text { Impacts }\end{array}$ & Social Impacts \\
\hline A1 & no breakwater & $\begin{array}{c}\text { no breakwater } \\
\text { construction }\end{array}$ & none & none & none & $\mathrm{n} / \mathrm{a}$ & $\mathrm{n} / \mathrm{a}$ \\
\hline A2 & $\begin{array}{l}\text { made of large stone } \\
\text { elements, connected to the } \\
\text { shore (length } 100 \mathrm{~m} \text {, crest } \\
\text { height }-2.0 \mathrm{~m} \text { and width } \\
6.0 \mathrm{~m} \text {, the crest altitude on } \\
\text { the beach side is higher } \\
-1.5 \mathrm{~m} \text { for beach protection, } \\
\text { max. depth is }-6.5 \mathrm{~m} \text {, } \\
\text { volume } 2150 \mathrm{~m}^{3} \text { ) }\end{array}$ & $\begin{array}{l}\text { simpler and cheaper than } \\
\text { the construction of the } \\
\text { breakwater in alternative } \\
\text { A4 and A5 because it is } \\
\text { possible to construct it by } \\
\text { filling the material from } \\
\text { the shore- - without } \\
\text { offshore construction } \\
\text { equipment }\end{array}$ & $\begin{array}{c}\text { av. by } \\
17 \% \text {, } \\
\text { max. by } \\
23 \%\end{array}$ & $\begin{array}{l}\text { high, energy } \\
\text { is dissipated } \\
\text { very close to } \\
\text { the structure }\end{array}$ & $\begin{array}{c}\text { provides } \\
\text { protection for } \\
\text { natural beach } \\
\text { material, protects } \\
\text { the structure } \\
\text { from scouring }\end{array}$ & $\begin{array}{c}\text { provides a } \\
\text { significant area } \\
\text { near the coastline } \\
\text { for new bio habitat }\end{array}$ & $\begin{array}{l}\text { some negative } \\
\text { impacts during } \\
\text { extreme ebb phases, } \\
\text { due to reduced } \\
\text { water depth and } \\
\text { unappealing sea bed } \\
\text { where swimmers } \\
\text { enter the water }\end{array}$ \\
\hline A3 & $\begin{array}{l}\text { made of large stone } \\
\text { elements, connected to the } \\
\text { shore }(4.0 \mathrm{~m} \text { wider than } \mathrm{A} 2 \text {, } \\
\text { length } 110 \mathrm{~m} \text {, crest height } \\
-2.0 \mathrm{~m} \text {, the crest altitude on } \\
\text { the beach side is higher } \\
-1.5 \mathrm{~m} \text { for beach protection, } \\
\text { max. depth is }-7.5 \mathrm{~m} \text {, } \\
\left.\text { volume } 2870 \mathrm{~m}^{3}\right)\end{array}$ & $\begin{array}{l}\text { simpler and cheaper than } \\
\text { the construction of the } \\
\text { breakwater in alternative } \\
\text { A4 and A5 because it is } \\
\text { possible to construct it by } \\
\text { filling the material from } \\
\text { the shore- without } \\
\text { offshore construction } \\
\text { equipment, more material } \\
\text { is needed than in A2 }\end{array}$ & $\begin{array}{c}\text { av. by } \\
18 \% \text {, } \\
\text { max. by } \\
28 \%\end{array}$ & $\begin{array}{l}\text { high, energy } \\
\text { is dissipated } \\
\text { close to the } \\
\text { structure }\end{array}$ & $\begin{array}{l}\text { provides } \\
\text { protection for } \\
\text { natural beach } \\
\text { material, protects } \\
\text { the structure } \\
\text { from scouring, } \\
\text { slightly better } \\
\text { than A2 }\end{array}$ & $\begin{array}{c}\text { provides a } \\
\text { significant area } \\
\text { near the coastline } \\
\text { for new bio habitat, } \\
\text { better than A2, A4, } \\
\text { A5 }\end{array}$ & $\begin{array}{l}\text { some negative } \\
\text { impacts during } \\
\text { extreme ebb phases, } \\
\text { due to reduced } \\
\text { water depth and } \\
\text { unappealing sea bed } \\
\text { where swimmers } \\
\text { enter the water } \\
\text { (similar to A2) }\end{array}$ \\
\hline A4 & $\begin{array}{l}\text { made of large stone } \\
\text { elements, with a } \\
\text { trapezoidal cross-section } \\
\text { detached from shore } \\
\text { (length } 110 \mathrm{~m} \text {, crest height } \\
-2.0 \mathrm{~m} \text { and width } 6.0 \mathrm{~m} \text {, the } \\
\text { axis is at an average depth } \\
\text { of }-5.0 \mathrm{~m} \text {, volume } 3200 \mathrm{~m}^{3} \text { ) }\end{array}$ & $\begin{array}{l}\text { complex and more } \\
\text { expensive than A2 and A3 } \\
\text { because of the distance of } \\
\text { the breakwater from shore } \\
\text { and need for offshore } \\
\text { construction equipment }\end{array}$ & $\begin{array}{c}\text { av. by } \\
15 \% \text {, } \\
\text { max. by } \\
28 \%\end{array}$ & $\begin{array}{l}\text { high, energy } \\
\text { is dissipated } \\
\text { far from the } \\
\text { structure }\end{array}$ & $\begin{array}{c}\text { provides } \\
\text { protection for } \\
\text { natural beach } \\
\text { material, does } \\
\text { not protect the } \\
\text { structure from } \\
\text { scouring, similar } \\
\text { to A5, worse } \\
\text { than A2 }\end{array}$ & $\begin{array}{l}\text { provides a } \\
\text { significant area far } \\
\text { from the coastline } \\
\text { for new bio habitat, } \\
\text { similar to A2, A5 }\end{array}$ & $\begin{array}{c}\text { insignificant impact } \\
\text { during extreme ebb } \\
\text { phases for potential } \\
\text { boat approach }\end{array}$ \\
\hline A5 & $\begin{array}{c}\text { made of large stone } \\
\text { elements, with trapezoidal }\end{array}$ & $\begin{array}{c}\text { complex and more } \\
\text { expensive than } \mathrm{A} 2 \text { and } \mathrm{A} 3\end{array}$ & $\begin{array}{l}\text { av. by } \\
17 \%,\end{array}$ & $\begin{array}{l}\text { high, energy } \\
\text { is dissipated }\end{array}$ & $\begin{array}{l}\text { provides } \\
\text { protection for }\end{array}$ & $\begin{array}{c}\text { provides a } \\
\text { significant area far }\end{array}$ & $\begin{array}{l}\text { insignificant impact } \\
\text { during extreme ebb }\end{array}$ \\
\hline
\end{tabular}




\begin{tabular}{|c|c|c|c|c|c|c|}
\hline $\begin{array}{c}\text { cross-section detached } \\
\text { from shore (length } 125 \mathrm{~m} \text {, } \\
\text { crest height }-2.0 \mathrm{~m} \text { and } \\
\text { width } 6.0 \mathrm{~m} \text {, the } \\
\text { breakwater axis is at an } \\
\text { average depth of }-6.0 \mathrm{~m} \text {, } \\
\text { volume of material } \\
\left.4100 \mathrm{~m}^{3}\right)\end{array}$ & $\begin{array}{l}\text { because of the distance of } \\
\text { the breakwater from shore } \\
\text { and need for offshore } \\
\text { construction equipment, } \\
\text { more material is needed } \\
\text { than in A4 }\end{array}$ & $\begin{array}{c}\text { max. by } \\
33 \%\end{array}$ & $\begin{array}{l}\text { very far from } \\
\text { the structure }\end{array}$ & $\begin{array}{c}\text { natural beach } \\
\text { material, does } \\
\text { not protect the } \\
\text { structure from } \\
\text { scouring similar } \\
\text { to A4 and worse } \\
\text { than A2 }\end{array}$ & $\begin{array}{l}\text { from the coastline } \\
\text { for new bio habitat, } \\
\text { similar to A2 and } \\
\text { A4 }\end{array}$ & $\begin{array}{l}\text { phases for potential } \\
\text { boat approach }\end{array}$ \\
\hline
\end{tabular}


The technical criterion $(\mathrm{T})$ is divided into the following three sub-criteria:

- $\quad$ the decrease in the significant wave height along the new and existing coastal structure (T1) this is directly related to the wave forces acting on the structure (stronger reduction of the wave heights suggests lower wave forces and less potential damages to the structure);

- the dissipation of the wave energy (T2) - the wave energy should be dissipated as much as possible and as far as possible from the structure to ensure that no breaking waves reach the beach structure; and

- the effect on the protection of the newly built coastal structure (T3) - coastal structures, such as the concrete walls, can be vulnerable to the scouring at the toe, which may have a negative impact on the structure stability, therefore a rubble protection placed in front of the concrete wall has an additional positive effect.

The economic criterion (EC) is divided into the following two sub-criteria:

- the complexity of the structure of the breakwater (EC1) - if the breakwater is placed close to (in front of) the coastal wall, it can be built directly from the beach, which is more practical and less expensive than building a detached breakwater from a floating equipment; and

- the volume of the breakwater (how much material is needed) (EC2)-the volume of the breakwater is directly related to the volume of rubble mound material and the price of the construction.

The environmental criterion (EN) evaluates the impact of alternatives on the improvement of the habitat conditions. The breakwater provides both food and refuge for the fish, therefore the surface area is positively correlated with the number and diversity of local species [12].

The social criterion (S) analyses the impact of alternatives on swimmers (the entrance in the water) and for boat approaches to the shore. The depth of the breakwater crown is positioned $2.0 \mathrm{~m}$ below sea level, which is deep enough not to pose an obstacle to swimmers or the approach of small boats. However, during extreme ebb phases, swimmers may feel the bottom consisting of large stone blocks when entering the sea, which may be less comfortable in comparison to the natural sea bottom. This may present a negative effect on the breakwater positioned in front of the beach. On the other hand, detached breakwaters do not affect the swimmers, but they may pose an issue for the approach of slightly larger boats during an extreme ebb phase, which is less likely in this location.

The importance that is given to criteria (Scenario S1) based on the authors' expert judgement was: $30 \%$ for the technical criteria (33.33\% for each sub-criterion), $40 \%$ for the economic criteria (of which $40 \%$ for the sub-criterion EC1, and $60 \%$ for the sub-criterion EC2), $15 \%$ each for environmental (EN), and social criterion (S). The technical and economic criteria were given more importance than the environmental or social criterion in this case, because the environmental and social impacts are not crucial for a construction of these dimensions. Between the technical and economic criteria, a slight advantage was given to the economic criteria because the technical ones - the dissipation of wave energy and reduction of wave heights - were very similar when comparing the considered alternatives.

\subsection{Pairwise Comparison of Alternatives}

The pair-wise comparison of the alternatives A2 to A5, with respect to each criterion (subcriterion), was performed based on the data and descriptions of alternatives presented in Table 2 using the pair-wise comparison scale from Table 1. Table 3 shows the preferences of each alternative (given in rows) in relation to other alternatives (given in columns) with respect to a specific criterion (sub-criterion). A positive value indicates that the alternative in that row is better than the alternative in a corresponding column.

The inconsistency of the pairwise comparison of alternatives is 0.00 for EC2, EN and $S ; 0.03$ for T3 and EC2; 0.04 for T2; and 0.05 for T1. Therefore, the assessment is consistent.

Table 3. Pairwise comparison of alternatives. 


\begin{tabular}{|c|c|c|c|c|c|c|c|c|c|c|c|c|c|c|}
\hline T1 & A2 & A3 & A4 & A5 & $\mathrm{T} 2$ & A2 & A3 & A4 & A5 & T3 & $\mathrm{A} 2$ & A3 & A4 & A5 \\
\hline A2 & & -4 & -3 & -6 & $\mathrm{~A} 2$ & & -3 & -5 & -7 & $\mathrm{~A} 2$ & & -2 & 7 & 7 \\
\hline A3 & & & 3 & -3 & A3 & & & -3 & -5 & A3 & & & 8 & 8 \\
\hline A4 4 & & & & -4 & $\mathrm{~A} 4$ & & & & -3 & $\mathrm{~A} 4$ & & & & 1 \\
\hline A5 & & & & & A5 & & & & & A5 & & & & \\
\hline EC1 & A2 & A3 & A4 & A5 & EC2 & A2 & A3 & $\mathrm{A} 4$ & A5 & & & & & \\
\hline $\mathrm{A} 2$ & & 1 & 5 & 5 & $\mathrm{~A} 2$ & & 3 & 5 & 7 & & & & & \\
\hline A3 & & & 5 & 5 & A3 & & & 3 & 5 & & & & & \\
\hline $\mathrm{A} 4$ & & & & 1 & $\mathrm{~A} 4$ & & & & 3 & & & & & \\
\hline A5 & & & & & A5 & & & & & & & & & \\
\hline EN & A2 & A3 & A4 & A5 & & & & & & & & & & \\
\hline $\mathrm{A} 2$ & & -3 & 1 & 1 & & & & & & & & & & \\
\hline A3 & & & 3 & 3 & & & & & & & & & & \\
\hline $\mathrm{A} 4$ & & & & 1 & & & & & & & & & & \\
\hline A5 & & & & & & & & & & & & & & \\
\hline$S$ & A2 & A3 & A4 & A5 & & & & & & & & & & \\
\hline A2 & & 1 & -3 & -3 & & & & & & & & & & \\
\hline A3 & & & -3 & -3 & & & & & & & & & & \\
\hline A4 & & & & 1 & & & & & & & & & & \\
\hline A5 & & & & & & & & & & & & & & \\
\hline
\end{tabular}

\subsection{Results from $A H P$}

Based on the analysis performed using the AHP method (and the ideal synthesis mode) according to the selected criteria importance (Scenario S1), the best alternative is A3 (0.334), followed by A2 (0.272), A5 (0.219) and A4 (0.175), as presented in Figure 3. The overall consistency is 0.02 . A more detailed insight in the final ranking is given in Figure 4 derived from the sensitivity graph.

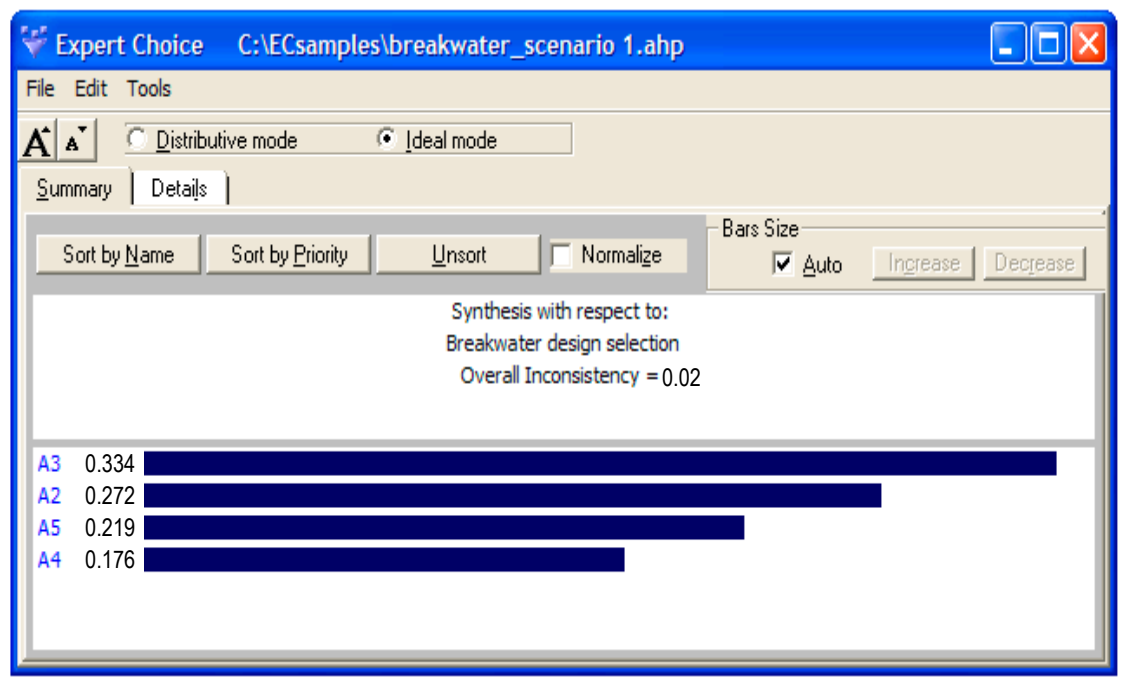

Figure 3. Result of the AHP method application for Scenario S1.

To test the sensitivity, four more scenarios of criteria importance were considered and evaluated:

- Scenario S2: T 25\%, EC 35\%, EN 30\% and S 10\% - more importance is given to the environmental criterion; technical, economic and social criteria are given less importance in comparison to S1;

- Scenario S3: T 45\%, EC 35\%, EN 10\% and S 10\%-more importance is given to the technical criterion; economic, environmental and social criteria are given less importance in comparison to S1;

- Scenario S4: T 40\%, EC 30\%, EN 15\% and S 15\%-more importance is given to the technical criterion, less to economic one, with no change in the environmental and social criteria importance in comparison to S1; and 
- Scenario S5: T 30\%, EC 50\%, EN 10\% and S 10\%-more importance is given to the economic criterion, less to the technical, environmental and social criteria in comparison to S1.

The importance of sub-criteria was not changed. Results of the AHP analyses based on all the criteria importance scenarios are presented in Table 4.

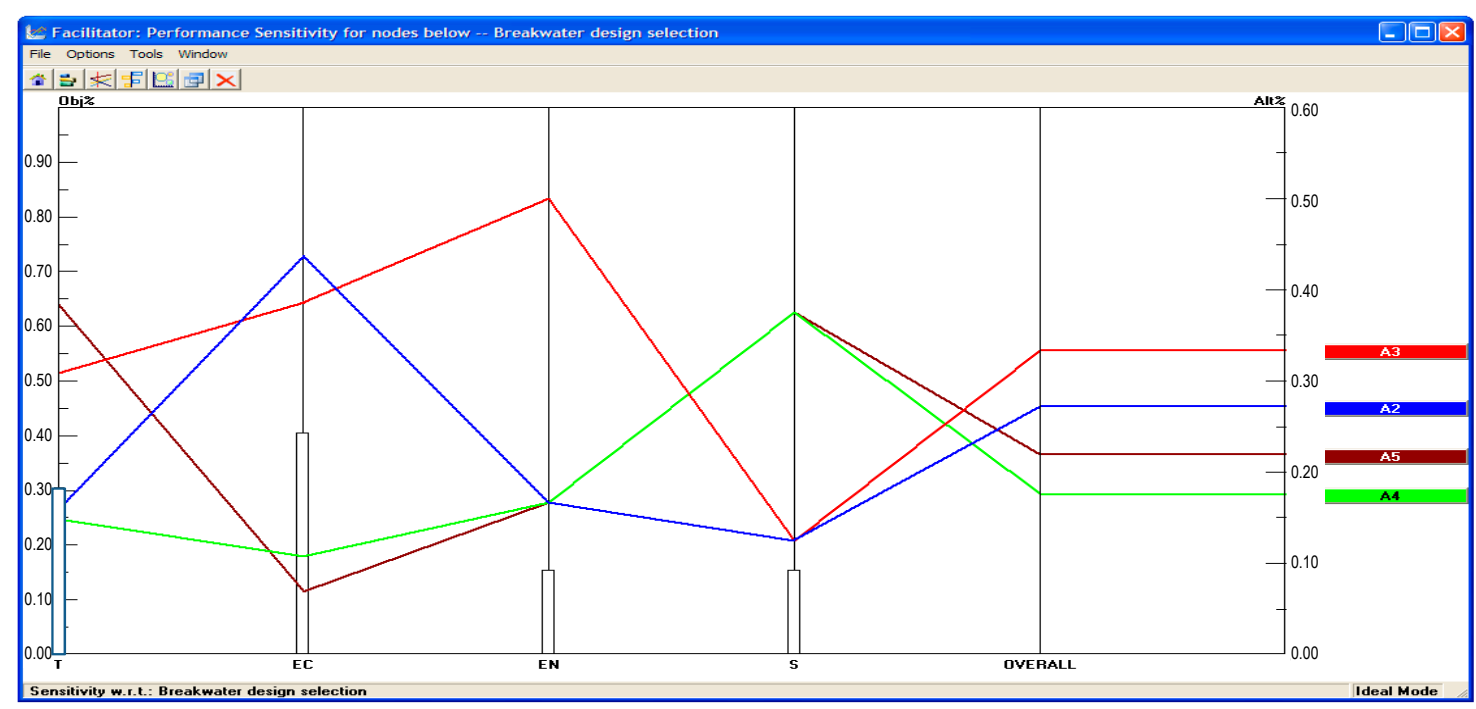

Figure 4. Performance sensitivity for Scenario S1.

Table 4. Result of AHP application on 5 different criteria scenarios.

\begin{tabular}{cccccc}
\hline \multirow{2}{*}{ Rank } & \multicolumn{5}{c}{ Scenario } \\
\cline { 2 - 6 } & S1 & S2 & S3 & S4 & S5 \\
\hline \multirow{2}{*}{1} & A3 & A3 & A3 & A3 & A3 \\
& $(0.334)$ & $(0.369)$ & $(0.333)$ & $(0.326)$ & $(0.345)$ \\
\multirow{2}{*}{2} & A2 & A2 & A2 & A5 & A2 \\
& $(0.272)$ & $(0.262)$ & $(0.262)$ & $(0.249)$ & $(0.303)$ \\
\multirow{2}{*}{3} & A5 & A5 & A5 & A2 & A5 \\
& $(0.219)$ & $(0.203)$ & $(0.241)$ & $(0.244)$ & $(0.196)$ \\
\multirow{2}{*}{4} & A4 & A4 & A4 & A4 & A4 \\
& $(0.175)$ & $(0.167)$ & $(0.163)$ & $(0.181)$ & $(0.157)$ \\
\hline
\end{tabular}

\section{Discussion and Conclusions}

The alternative A3 was ranked as the best solution (optimal design of the breakwater) in all the criteria importance scenarios (Table 4). If only the technical criterion was applied, the best alternative would be A5, while A2 would be the best if only the economic criterion was considered. The possibility to include both environmental and social criteria in addition to technical and economic criteria provides a more holistic assessment of the potential benefits and impacts of each alternative, and helps to form a more reliable decision.

The advantage of the AHP method, the possibility to make a pair-wise comparison of the alternatives according to each criterion (both quantitatively and qualitatively), has proven to be useful in selecting the design of breakwater since not all criteria could have been quantitatively assessed in this planning stage. The analyses proved that the AHP method is a useful tool for decision making when selecting an optimal design of coastal structures, such as breakwaters. Further research will focus on: more detailed numerical modelling of coastal processes [13], combining quantitative and qualitative criteria, more detailed selection and quantification of social and environmental criteria, and the inclusion of stakeholders in the process of decision making. 
Author Contributions: Conceptualization, B.K.; methodology, B.K., N.K., I.R.; software, B.K., N.K., I.R.; validation, B.K., N.K., I.R.; formal analysis, B.K.; investigation, B.K., N.K., I.R.; resources, B.K.; data curation, B.K., N.K.; writing-original draft preparation, B.K., N.K., I.R.; writing-review and editing, B.K., N.K., I.R.; project administration, B.K.; funding acquisition, B.K. All authors have read and agreed to the published version of the manuscript.

Funding: This research was funded by the University of Rijeka projects: Implementation of innovative methodologies, approaches and tools for sustainable river basin management (uniri-tehnic-18-129), Hydrology of water resources and identification of flood and mudflow risks in karst (uniri-technic-18-54) and Geo-hazard in Kvarner Bay area (uniri-tehnic-18-97).

Conflicts of Interest: The authors declare no conflict of interest.

\section{References}

1. Triantaphyllou, E. Multi-Criteria Decision Making Methods: A Comparative Study; Kluwer Academic Publishers: Dordrecht, The Netherlands, 2000; ISBN 978-0-7923-6607-2, doi:10.1007/978-1-4757-3157-6.

2. Figueira, J.; Greco, S.; Ehrogott, M. Multiple Criteria Decision Analysis: State of the Art Surveys. In International Series in Operations Research E Management Science; Springer: New York, NY, USA, 2005; Volume 78, ISBN 978-0-387-23081-8, doi:10.1007/b100605.

3. Huang, I.B.; Keisler, J.; Linkov, I. Multi-criteria decision analysis in environmental sciences: Ten years of applications and trends. Sci. Total Environ. 2011, 409, 3578-3794, doi:10.1016/j.scitotenv.2011.06.022.

4. Hajkowicz, S.; Collins, K. A Review of Multiple Criteria Analysis for Water Resource Planning and Management. Water Resour. Manag. 2007, 21, 1553-1566, doi:10.1007/s11269-006-9112-5.

5. Serafim, M.B.; Siegle, E.; Corsi, A.C.; Bonetti, J. Coastal vulnerability to wave impacts using a multi-criteria index: Santa Catarina (Brazil). J. Environ. Manag. 2019, 230, 21-32, doi:10.1016/j.jenvman.2018.09.052.

6. Papatheochari, T.; Coccossis, H. Development of a waterfront regeneration tool to support local decision making in the context of integrated coastal zone management. Ocean Coast. Manag. 2019, 169, 284-295, doi:10.1016/j.ocecoaman.2018.12.013.

7. Zavadskas, E.K.; Turskis, Z.; Bagočius, V. Multi-criteria selection of a deep-water port in the Eastern Baltic Sea. Appl. Soft Comput. 2015, 26, 180-192, doi:10.1016/j.asoc.2014.09.019.

8. Johnston, A.; Slovinsky, P.; Yates, K.L. Assessing the vulnerability of coastal infrastructure to sea level rise using multi-criteria analysis in Scarborough, Maine (USA). Ocean Coast. Manag. 2014, 95, 176-188, doi:10.1016/j.ocecoaman.2014.04.016.

9. Saaty, T.L. The Analytic Hierarchy Process, 2nd ed.; RWS Publications: Pittsburg, CA, USA, 1996.

10. Grahovac, A.; Krvavica, N.; Ružić, I. Seawall construction impact on wave dynamics of natural coast. Zbornik Radova Građevinskog Fakulteta u Rijeci 2018, 21, 179-191, doi:10.32762/zr.21.1.11. (In Croatian)

11. Booij, N.; Ris, R.C.; Holthuijsen, L.H. A third-generation wave model for coastal regions, Part I: Model description and validation. J. Geophys. Res. 1999, 104, 7649-7666, doi:10.1029/98JC02622.

12. Pizzolon, M.; Cenci, E.; Mazzoldi, C. The onset of fish colonization in a coastal defence structure (Chioggia, Northern Adriatic Sea). Estuar. Coast. Shelf Sci. 2008, 78, 166-178, doi:10.1016/j.ecss.2007.11.014.

13. Postacchini, M.; Lalli, F.; Memmola, F.; Bruschi, A.; Bellafiore, D.; Lisi, I.; Zitti G.; Brocchini, M. Model chain approach for coastal inundation: Application to the bay of Alghero. Est. Coast. Shelf Sci. 2019, 219, 56-70. 